\title{
Article \\ Novel Process of Reduction Roasting Manganese Ore with Sulfur Waste and Extraction of Mn by Acid Leaching
}

\author{
Yongjie Liu ${ }^{1}$, Fupeng $\mathrm{He}^{1}$, Donglai Ma ${ }^{1}$, Qingqing $\mathrm{Hu}^{1}$ and Zhixiong You ${ }^{1,2, *}$ \\ 1 College of Materials Science and Engineering, Chongqing University, Chongqing 400044, China; \\ liuyongjie@cqu.edu.cn (Y.L.); 202109021064@cqu.edu.cn (F.H.); mdl18862609919@163.com (D.M.); \\ huqq1228@163.com (Q.H.) \\ 2 Chongqing Key Laboratory of Vanadium-Titanium Metallurgy and Advanced Materials, Chongqing \\ University, Chongqing 400044, China \\ * Correspondence: youzx@cqu.edu.cn; Tel./Fax: +86-023-65112631
}

Citation: Liu, Y.; He, F.; Ma, D.; Hu, Q.; You, Z. Novel Process of Reduction Roasting Manganese Ore with Sulfur Waste and Extraction of Mn by Acid Leaching. Metals 2022, 12, 384. https://doi.org/10.3390/ met12030384

Academic Editor: Jean François Blais

Received: 12 January 2022

Accepted: 16 February 2022

Published: 23 February 2022

Publisher's Note: MDPI stays neutral with regard to jurisdictional claims in published maps and institutional affiliations.

Copyright: (C) 2022 by the authors. Licensee MDPI, Basel, Switzerland. This article is an open access article distributed under the terms and conditions of the Creative Commons Attribution (CC BY) license (https:// creativecommons.org/licenses/by/ $4.0 /)$.

\begin{abstract}
Manganese dioxide is typically reduced to a bivalent state before being extracted; here, sulfur is considered an efficient reductant and sulfur-based reduction has been industrialized in China. In this study, the reaction mechanism between $\mathrm{MnO}_{2}$ and gaseous sulfur was investigated. Thermodynamically, the reduction of $\mathrm{MnO}_{2}$ by gaseous sulfur is feasible. The predominant phase diagram as functions of temperature and input $\mathrm{S}_{2}(\mathrm{~g})$ fraction in the $\mathrm{S}_{2}-\mathrm{MnO}_{2}$ system was calculated. Experimental validation showed that $\mathrm{MnO}_{2}$ was reduced stepwise to low-valence manganese oxides and manganese sulfate. The phase composition of the roasted products was complex, and MnS was inevitably formed. The valence state as well as microstructure of manganese dioxide during reduction roasting were also investigated by X-ray photoelectron spectroscopy (XPS) and scanning electron microscopy-energy-dispersive spectroscopy (SEM-EDS). The reaction process could be described by an unreacted nuclear model. Manganese was extracted by sulfuric acid solution after reduction by sulfur waste. In sulfuric acid, $95.2 \mathrm{wt} \% \mathrm{Mn}$ extraction was achieved, using a roasting temperature of $450{ }^{\circ} \mathrm{C}$, roasting time of $30 \mathrm{~min}$, and $\mathrm{S}_{2} / \mathrm{MnO}_{2}$ molar ratio of 0.40 . With the same conditions, low Fe extraction was achieved. On the other hand, in deionized water, $24.3 \mathrm{wt} \% \mathrm{Mn}$ extraction was achieved, confirming the formation of $\mathrm{MnSO}_{4}$.
\end{abstract}

Keywords: manganese dioxide; sulfur; reduction roasting; acid leaching; reaction mechanism

\section{Introduction}

Manganese is the fourth most widely used metal after iron, aluminum, and copper. It is used in numerous fields, such as ferrous and non-ferrous metallurgy, batteries, the chemical industry, agriculture, and animal husbandry [1-3]. Manganese carbonate and oxide ores are two primary resources for extracting Mn. Manganese carbonate ore is valuable because $\mathrm{Mn}(\mathrm{II})$ is soluble in acid solutions, making the extraction process extremely simple. However, globally, its availability is limited. Manganese oxide ores are extensively employed for manganese production [4-6]. Mn is always present in minerals as a highvalence oxide, such as pyrolusite $\left(\mathrm{MnO}_{2}\right)$, which constitutes $60 \%$ of the global manganese reserve. As $\mathrm{MnO}_{2}$ is stable under direct acidic and alkaline conditions, it is necessary to convert the insoluble $\mathrm{Mn}(\mathrm{IV})$ into soluble $\mathrm{Mn}(\mathrm{II})$ before leaching Mn from oxide ore [7].

The reduction of $\mathrm{Mn}(\mathrm{IV})$ from oxide ores can proceed via routes such as pyrometallurgy, hydrometallurgy, and bio-hydrometallurgy. The type of a reducing agent is key for Mn extraction. Thus far, many reductants have been explored for reducing Mn(IV), such as carbon-based, sulfur-based, hydrogen-based [8,9], metal-based, and miscellaneous reductants. Carbon-based reductants include coal [10], graphite, and $\mathrm{CO}$, while sulfur-based reductants include elemental sulfur [11], $\mathrm{SO}_{2}$ [12], $\mathrm{Na}_{2} \mathrm{SO}_{3},\left(\mathrm{NH}_{4}\right)_{2} \mathrm{SO}_{3}$ [13], $\mathrm{H}_{2} \mathrm{SO}_{4}, \mathrm{CaS}$ and $\mathrm{Na}_{2} \mathrm{~S}_{2} \mathrm{O}_{3}$. Iron powder [14], ferrous sulfate, and other iron salts can be used as metalbased reductants. Pyrite $\left(\mathrm{FeS}_{2}\right)$ [15], $\mathrm{CH}_{4}$, organics compounds [16], and biomass [17] are 
classified as miscellaneous reductants, as they comprise two reducing elements. Hydrogen peroxide has also been employed as a reductant on the laboratory scale [18].

In the process of desulfurization of oil, natural gas, and coal gas, a considerable amount of low-quality sulfur sludge, sulfur mud, and sulfur slurry is produced as hazardous waste $[19,20]$. Not only that, the hydrometallurgical recovery of metals from sulfide concentrates, such as chalcopyrite, enargite, and sphalerite, typically generates elemental sulfur in the oxidative leaching processes [21]. The elemental sulfur content of direct leaching residue can exceed $70 \%$. Due to the existence of active elemental sulfur, conventional means, such as incineration or landfill, are incapable of handling the sulfur-bearing hazardous wastes. Considering the growing number of environmental problems, the ways of waste re-use in production and new material installation are expanding [22,23]. The waste can be re-consumed for production of construction material such as asphalt, concrete or applied in the development of new products, such as copolymers, lithium-sulfur batteries, etc. Despite the broad range of recycling techniques available, a big share of byproducts consisting of sulfur compounds is still stored in a form of stable sulfate rocks such as gypsum or anhydrite.

In recent years, sulfur-based reduction or sulfidation using elemental sulfur as a reductant has gained considerable research attention, because sulfur (pure sulfur can be replaced by sulfur waste) is a high-efficiency reductant. An alternative process, viz., the reduction roasting of manganese oxide ore with elemental sulfur prior to acid leaching, has been successfully developed $[11,24,25]$. Sulfur-based reduction has also been industrialized in China, using a fluid-bed furnace (ebullated furnace) as the main roasting device [26]. Therein, sulfur was sublimated or gasified in the ebullated furnace because of the low boiling point of elemental sulfur. This implies that gaseous sulfur was the main reducing agent during reduction. The $\mathrm{SO}_{2}$ gas generated during reduction roasting can be absorbed to prepare sulfuric acid and then used for acid leaching. Hence, in this study, to explore the reduction mechanism of manganese dioxide $\left(\mathrm{MnO}_{2}\right)$ using a gaseous reducing agent, the phase transformation, valence state changes, and microstructure were investigated using $\mathrm{X}$-ray diffraction (XRD), X-ray photoelectron spectroscopy (XPS), and scanning electron microscopy-energy-dispersive spectroscopy (SEM-EDS). The mechanism of reduction roasting was investigated via thermodynamic analysis and experimentation. Reduction roasting followed by acid leaching was also conducted to extract $\mathrm{Mn}$ from a manganese oxide ore.

\section{Experimental}

\subsection{Materials}

\subsubsection{Sulfur Waste}

Solid sulfur (powder) with a purity greater than $99.99 \mathrm{wt} \%$ was used as a reducing agent for investigating the reaction mechanism of manganese dioxide. Sulfur waste, obtained from an oxygen pressure leaching sphalerite process, was used for extraction of Mn from low-grade Mn ore. The purity of S in the sulfur waste was $85.51 \mathrm{wt} \%$. The XRD results in Figure 1 indicate that the main phases in sulfur waste were elemental sulfur (S) and residual sphalerite (ZnS). The morphology of sulfur waste in Figure 2 reveal that its particle size was almost uniform. The particle size of sulfur waste is not critical because it will be sublimated for reduction. 


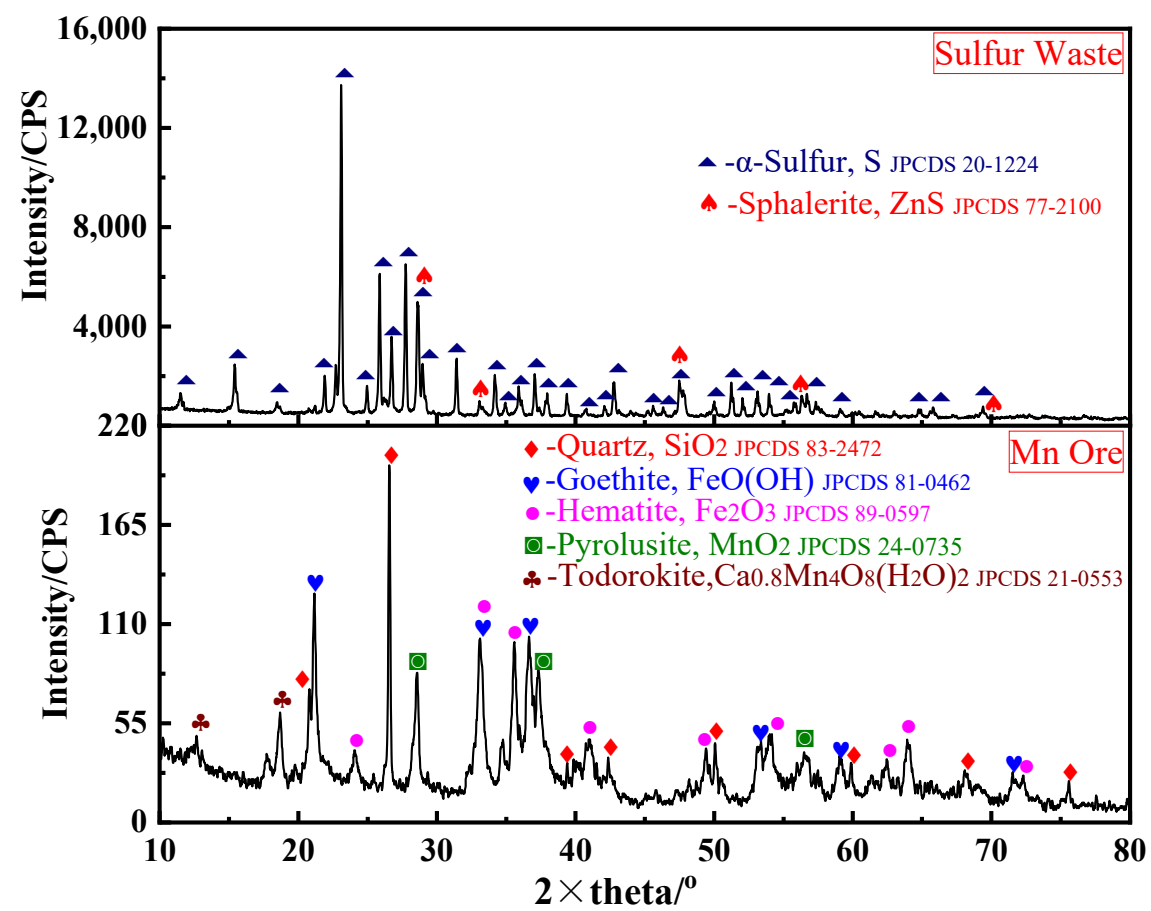

Figure 1. XRD patterns of the sulfur waste and manganese oxide ore.

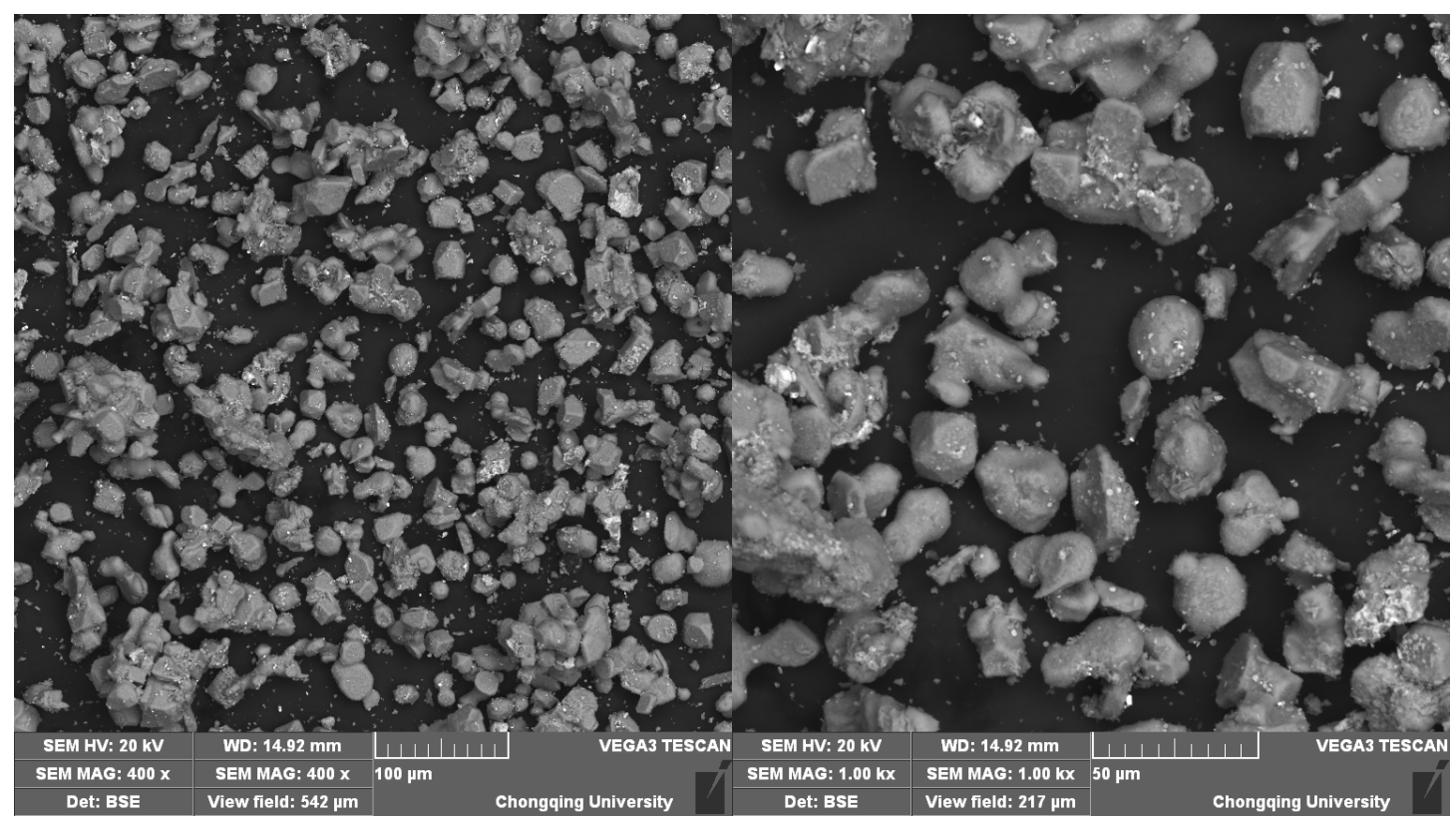

Figure 2. The morphology of sulfur waste.

\subsubsection{Mn-Bearing Materials}

The manganese oxide ore used in this study was obtained from Xiatian mine located in Xiangzhou County, Guangxi Province, China. The main chemical composition of the raw material, obtained by chemical analysis, is shown in Table 1 . The $S$ content was measured by Nacho carbon and sulfur analyzer (CS-3000, NCS Testing Technology CO., Ltd., Beijing, China). The total Mn and Fe contents (TMn, TFe) were $21.97 \mathrm{wt} \%$ and $28.70 \mathrm{wt} \%$, corresponding to $34.75 \mathrm{wt} \% \mathrm{MnO}_{2}$ and $41.00 \mathrm{wt} \% \mathrm{Fe}_{2} \mathrm{O}_{3}$, respectively. The gangue composition contained $8.32 \mathrm{wt} \% \mathrm{SiO}_{2}$ and $5.15 \mathrm{wt} \% \mathrm{Al}_{2} \mathrm{O}_{3}$. The XRD analysis of the raw material in Figure 1 indicates that the manganese ore is primarily composed of pyrolusite $\left(\mathrm{MnO}_{2}\right)$ and quartz $\left(\mathrm{SiO}_{2}\right)$. The $\mathrm{Mn}$-bearing mineral also contains todorokite 
$\left(\mathrm{Ca}_{0} \cdot{ }_{8} \mathrm{Mn}_{4} \mathrm{O}_{8}\left(\mathrm{H}_{2} \mathrm{O}\right)_{2}\right)$. The size of raw material was ground to approximately $80 \mathrm{wt} \%$ passing through $0.074 \mathrm{~mm}$ before its use in reduction roasting. In addition, chemically pure $\mathrm{MnO}_{2}$ was used to investigate the reaction mechanism.

Table 1. Main chemical composition of the manganese ore, $w \mathrm{t} \%$.

\begin{tabular}{cccccccccc}
\hline Material & $\mathbf{M n O}_{2}$ & $\mathbf{F e}_{2} \mathbf{O}_{3}$ & $\mathbf{S i O}_{2}$ & $\mathbf{C a O}$ & $\mathbf{M g O}$ & $\mathbf{A l}_{2} \mathbf{O}_{3}$ & $\mathbf{P}$ & $\mathbf{S}$ & $\mathbf{L O I}$ \\
\hline Manganese ore & 34.75 & 41.00 & 8.32 & 0.36 & 0.29 & 5.15 & 0.16 & 0.10 & 11.41 \\
\hline LOI: Loss on ignition. & & & & & & & & &
\end{tabular}

\subsection{Experimental Procedure}

A sealable stainless-steel reactor was used for reduction roasting. The reduction experiments were conducted in a muffle furnace (Hefei Kejing Material Technology Co., Ltd., Heifei, China), as shown in Figure 3. Before reduction roasting, the raw Mn material and elemental sulfur $\left(\mathrm{S}_{2} / \mathrm{MnO}_{2}\right.$ ranges from 0.25 to 0.50$)$ were loaded into the reactor separately, to prevent the Mn material being reduced directly by elemental sulfur. Next, the container carrying the sample was introduced into the hot zone of the muffle furnace, which was preheated to the desired temperature $\left(350-550^{\circ} \mathrm{C}\right)$. Upon heating, solid sulfur melted/gasified or sublimated, then contacted with the Mn-bearing sample. The sample was reduced at a given temperature for a certain period (10-50 min), during which time the furnace was aerated with $\mathrm{N}_{2}$ gas flowing at a rate of $3 \mathrm{~L} / \mathrm{min}$. Subsequently, the container was taken out and cooled naturally to room temperature. Finally, the reduced sample was collected and prepared for analysis and leaching tests.

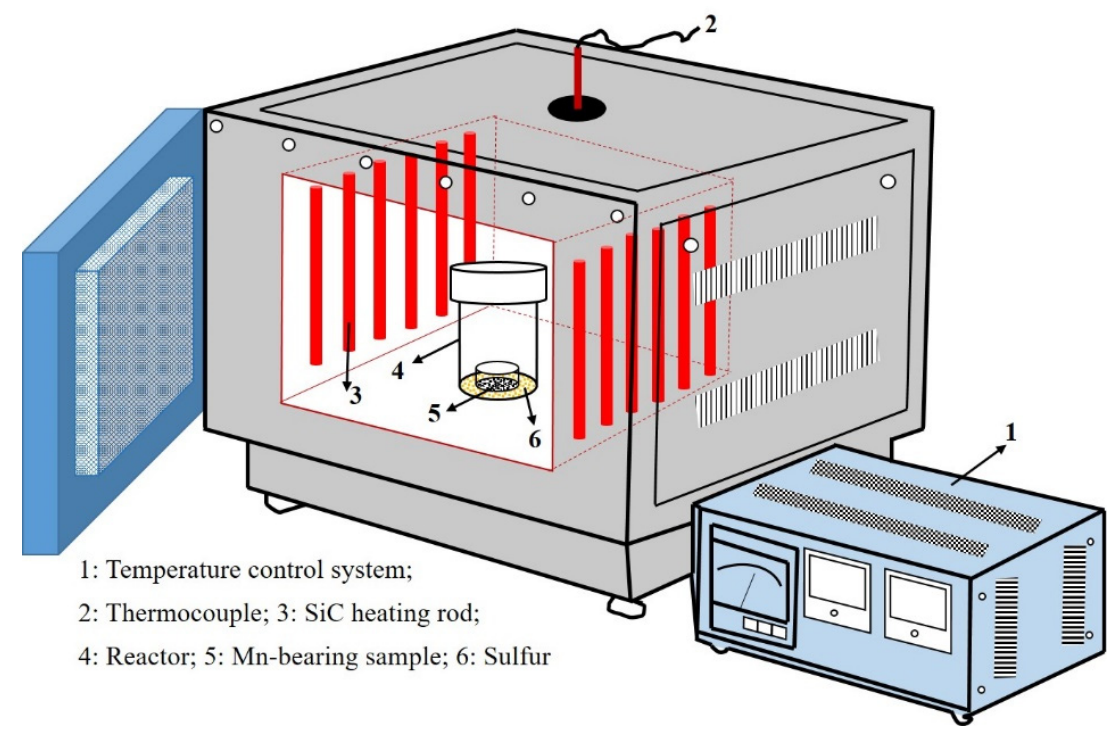

Figure 3. The schematic of roasting apparatus.

\subsection{Analytical Methods}

After reduction, the roasted samples were examined by X-ray powder diffraction (Rigaku D/max 2500, Rigaku, Tokyo, Japan ) using $\mathrm{Cu} \mathrm{K} \alpha$ radiation, a tube current of $250 \mathrm{~mA}$, voltage of $40 \mathrm{kV}, 2 \theta$ scanning range of $10-80^{\circ}, 2 \theta$ step size of $0.02^{\circ}$, and scanning speed of $8^{\circ} / \mathrm{min}$. SEM (JSM-7800F, Rigaku, Tokyo, Japan ) was performed to investigate the morphology of the powder, which was equipped with an EDAX energy dispersive $X$-ray spectroscopy (EDS) detector. SEM images were recorded in backscatter electron modes operating in low vacuum mode at 0.5 Torr and $20 \mathrm{keV}$. By the powder tableting method, the valence of different elements in the obtained powder was detected by XPS (ESCALAB250Xi, Thermo Fisher Scientific, Shanghai, China) under a vacuum of $10^{-10} \mathrm{mbar}$ at room temperature. High-resolution spectra were recorded with an analyzer (Thermo 
Fisher Scientific, Shanghai, China ) pass energy of $30 \mathrm{eV}$, and the binding energy (BE) of the obtained spectra was calibrated against the C $1 \mathrm{~s}$ photoelectron peak at $284.6 \mathrm{eV}$.

Thermodynamic analysis was conducted using the pure substances database of FactSage 8.0 (Montreal, Canada and Achen, Germany). The Mn content in the roasted products and residue was determined by chemical analysis. The detailed chemical analysis procedure has been described in the reference of [24].

The extraction ratio of $\mathrm{Mn}$ was calculated using the following equation:

$$
\gamma=\left(1-\frac{\mathrm{m}_{1} \times \beta}{\mathrm{m}_{0} \times \alpha}\right) \times 100 \%
$$

where $\gamma$ is the extraction ratio $(w \mathrm{t} \%), \mathrm{m}_{0}$ is the weight of the reduced product $(\mathrm{g}), \alpha$ is the Mn content of the reduced product $(\mathrm{wt} \%), \mathrm{m}_{1}$ is the weight of the leached residue $(\mathrm{g})$, and $\beta$ is the Mn content of the leached residue ( $w \mathrm{t} \%)$.

\section{Thermodynamic Analysis of Gaseous Sulfur-Based Reduction}

The equilibrium phase composition of the $\mathrm{MnO}_{2}-\mathrm{S}$ system can be calculated using FactSage 8.0. In this study, solid sulfur was used as the reducing agent for the reduction of $\mathrm{MnO}_{2}$. To determine the actual reaction agents that came in contact with $\mathrm{MnO}_{2}$, the behavior of solid sulfur was investigated. Figure 4 shows the phase composition for $1 \mathrm{~mol}$ solid sulfur in the temperature range of $400{ }^{\circ} \mathrm{C}$ to $600{ }^{\circ} \mathrm{C}$ at $1 \mathrm{~atm}$. According to the figure, solid sulfur first melted into the liquid form, because its melting point is only $119{ }^{\circ} \mathrm{C}$. Liquid sulfur was the sole phase in the temperature range of $400-470{ }^{\circ} \mathrm{C}$. By increasing temperature, liquid sulfur gasified to sulfur vapors with different sulfur atoms. The gaseous phases formed during heating were extremely complex. The phases, including $S_{8}, S_{7}$, and $\mathrm{S}_{6}$, were the main gaseous species, whose contents increased first and then decreased gradually with increasing temperature. Meanwhile, the $S_{2}(g)$ content increased steadily as the temperature increased, which indicated that the complex gaseous sulfur molecule decomposed to a simple sulfur molecule. Hence, $S_{2}(g)$ was determined as the main phase at high temperatures, and considered for the subsequent thermodynamic analysis.

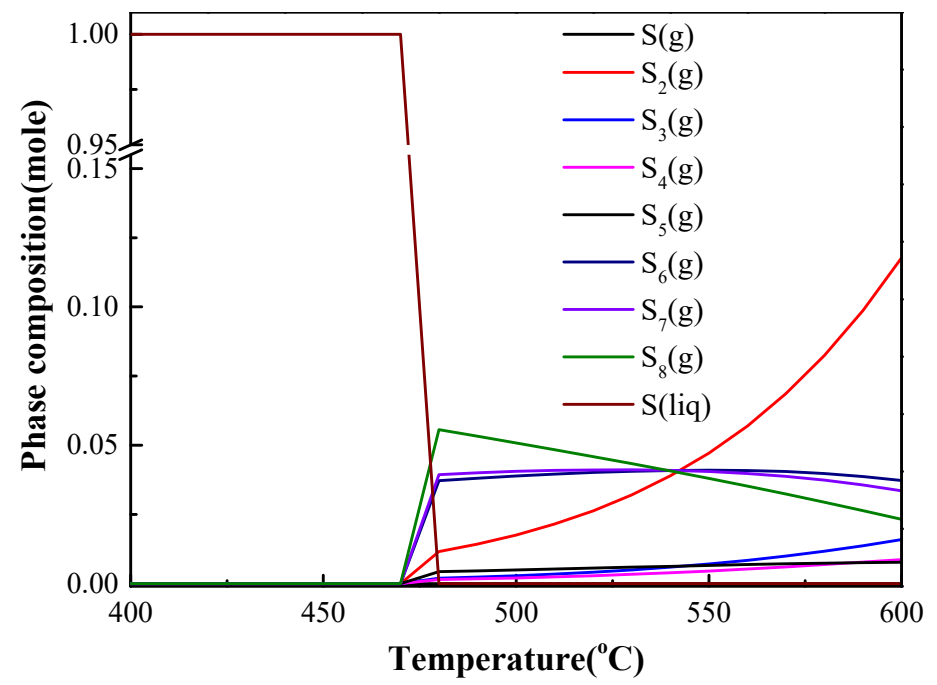

Figure 4. Phase composition as a function of temperature based on 1 mole solid sulfur.

The main reactions occurring in the $\mathrm{MnO}_{2}-\mathrm{S}_{2}(\mathrm{~g})$ system and their Gibbs energies are compared in Table 2. Most reactions occurred spontaneously or at low temperatures, which implies that the reduction of $\mathrm{MnO}_{2}$ by $\mathrm{S}_{2}(\mathrm{~g})$ was feasible. The equilibrium phase composition, as a function of the $\mathrm{S}_{2} / \mathrm{MnO}_{2}$ molar ratio and temperature, was also calculated, and the results are plotted in Figure $5 . \mathrm{MnO}_{2}$ was reduced stepwise to form low-valence manganese oxides and $\mathrm{MnSO}_{4}$ (or $\mathrm{SO}_{2}$ ). Comparison of reactions 2 and 3 revealed that 
$\mathrm{Mn}_{2} \mathrm{O}_{3}$ and $\mathrm{MnSO}_{4}$ were formed more easily than $\mathrm{SO}_{2}$ from the view of thermodynamics. The theoretical $\mathrm{S}_{2} / \mathrm{MnO}_{2}$ molar ratio was 0.10 (Table 2, Equation (5)); accordingly, the residual $\mathrm{MnO}_{2}$ decomposed when the molar ratio was less than 0.10 and the temperature was greater than $782 \mathrm{~K}$. Consequently, an area composed of $\mathrm{Mn}_{2} \mathrm{O}_{3}, \mathrm{MnSO}_{4}$, and gas $\left(\mathrm{O}_{2}\right)$ is seen in Figure 5. Since $\mathrm{MnO}_{2}$ was completely reduced, the reduction of $\mathrm{Mn}_{2} \mathrm{O}_{3}$ proceeded. The results in Table 2 and Figure 5 show that $\mathrm{Mn}_{3} \mathrm{O}_{4}$ and $\mathrm{MnSO}_{4}$ were preferentially generated (Equations (6) and (7)) in the calculated temperature range. Subsequently, $\mathrm{Mn}_{3} \mathrm{O}_{4}$ was reduced to form $\mathrm{MnO}$ and $\mathrm{MnSO}_{4}$ because the Gibbs energy of Equation (9) was the lowest (among Equations (8)-(11)). According to previous studies, $\mathrm{MnO}$ is acidsoluble, whereas $\mathrm{MnSO}_{4}$ is water-soluble. Thermodynamic calculation indicated that a $\mathrm{S}_{2} / \mathrm{MnO}_{2}$ molar ratio of $1 / 6$ was sufficient for properly converting $\mathrm{MnO}_{2}$ to $\mathrm{MnO}$ and $\mathrm{MnSO}_{4}$. Hence, $\mathrm{Mn}$ was leached during the subsequent acid leaching after roasting with a $\mathrm{S}_{2} / \mathrm{MnO}_{2}$ molar ratio of $1 / 6$.

$$
\mathrm{S}_{2}(\mathrm{~g})+6 \mathrm{MnO}_{2}=4 \mathrm{MnO}+2 \mathrm{MnSO}_{4}
$$

In addition, both $\mathrm{MnO}$ and $\mathrm{MnSO}_{4}$ can react further with sulfur to form different products; this largely depends on the roasting temperature and $\mathrm{S}_{2} / \mathrm{MnO}_{2}$ molar ratio. The reaction order and predominant field of various products are shown in Table 2 (Equations (12)-(15)) and Figure 5, respectively.

Table 2. Main reactions and their Gibbs energies as a function of temperature.

\begin{tabular}{cccc}
\hline Equations & Main Reactions & $\boldsymbol{\Delta}_{\mathbf{r}} \mathrm{G}^{\Theta} \mathbf{T} / \mathbf{k J} / \mathbf{m o l}$ & $\begin{array}{c}\text { Spontaneous } \\
\text { Reaction T/K }\end{array}$ \\
\hline$(3)$ & $4 \mathrm{MnO}_{2}=2 \mathrm{Mn}_{2} \mathrm{O}_{3}+\mathrm{O}_{2}(\mathrm{~g})$ & $166.568-0.213 \mathrm{~T}$ & $\mathrm{~T}>782 \mathrm{~K}$ \\
$(4)$ & $\mathrm{S}_{2}(\mathrm{~g})+8 \mathrm{MnO}_{2}=4 \mathrm{Mn}_{2} \mathrm{O}_{3}+2 \mathrm{SO}_{2}(\mathrm{~g})$ & $-390.985-0.279 \mathrm{~T}$ & Spontaneous \\
$(5)$ & $\mathrm{S}_{2}(\mathrm{~g})+10 \mathrm{MnO}_{2}=4 \mathrm{Mn}_{2} \mathrm{O}_{3}+2 \mathrm{MnSO}_{4}$ & $-872.778+0.070 \mathrm{~T}$ & Spontaneous \\
$(6)$ & $\mathrm{S}_{2}(\mathrm{~g})+12 \mathrm{Mn}_{2} \mathrm{O}_{3}=8 \mathrm{Mn}_{3} \mathrm{O}_{4}+2 \mathrm{SO}_{2}(\mathrm{~g})$ & $-339.479-0.165 \mathrm{~T}$ & Spontaneous \\
$(7)$ & $\mathrm{S}_{2}(\mathrm{~g})+16 \mathrm{Mn}_{2} \mathrm{O}_{3}=10 \mathrm{Mn}_{3} \mathrm{O}_{4}+2 \mathrm{MnSO}_{4}$ & $-808.395+0.213 \mathrm{~T}$ & $\mathrm{~T}<3795$ \\
$(8)$ & $\mathrm{S}_{2}(\mathrm{~g})+4 \mathrm{Mn}_{3} \mathrm{O}_{4}=12 \mathrm{MnO}+2 \mathrm{SO}_{2}(\mathrm{~g})$ & $199.734-0.360 \mathrm{~T}$ & $\mathrm{~T}>555$ \\
$(9)$ & $\mathrm{S}_{2}(\mathrm{~g})+6 \mathrm{Mn}_{3} \mathrm{O}_{4}=16 \mathrm{MnO}+2 \mathrm{MnSO}_{4}$ & $-89.445-0.047 \mathrm{~T}$ & Spontaneous \\
$(10)$ & $\mathrm{S}_{2}(\mathrm{~g})+2 / 5 \mathrm{Mn}_{3} \mathrm{O}_{4}=6 / 5 \mathrm{MnS}+4 / 5 \mathrm{SO}_{2}(\mathrm{~g})$ & $-68.194-0.004 \mathrm{~T}$ & $\mathrm{Spontaneous}$ \\
$(11)$ & $\mathrm{S}_{2}(\mathrm{~g})+2 / 3 \mathrm{Mn}_{3} \mathrm{O}_{4}=4 / 3 \mathrm{MnS}+2 / 3 \mathrm{MnSO}_{4}$ & $-194.357+0.140 \mathrm{~T}$ & $\mathrm{~T}<1192$ \\
$(12)$ & $\mathrm{S}_{2}(\mathrm{~g})+2 \mathrm{MnO}=3 / 2 \mathrm{MnS}+1 / 2 \mathrm{MnSO}_{4}$ & $-207.471+0.163 \mathrm{~T}$ & $\mathrm{~T}<1273$ \\
$(13)$ & $\mathrm{S}_{2}(\mathrm{~g})+4 / 3 \mathrm{MnO}=4 / 3 \mathrm{MnS}+2 / 3 \mathrm{SO}_{2}(\mathrm{~g})$ & $-97.964+0.036 \mathrm{~T}$ & $\mathrm{~T}<2721$ \\
$(14)$ & $\mathrm{S}(\mathrm{g})+\mathrm{MnSO}_{4}=\mathrm{MnS}+2 \mathrm{SO}_{2}(\mathrm{~g})$ & $121.050-0.220 \mathrm{~T}$ & $\mathrm{~T}>550$ \\
$(15)$ & $\mathrm{S}_{2}(\mathrm{~g})+4 \mathrm{MnSO}_{4}=4 \mathrm{MnO}+6 \mathrm{SO}_{2}(\mathrm{~g})$ & $778.091-0.986 \mathrm{~T}$ & $\mathrm{~T}>789$ \\
\hline
\end{tabular}

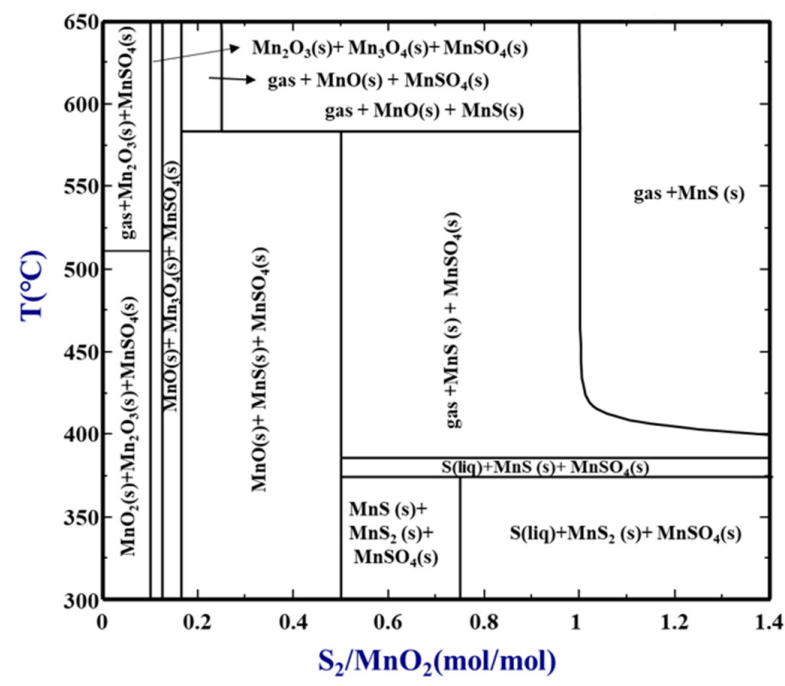

Figure 5. Predominant phase diagram as functions of temperature and input $S_{2}(g)$ fraction in the $\mathrm{S}_{2}-\mathrm{MnO}_{2}$ system. 


\section{Results and Discussion}

\subsection{Reaction Mechanism of Manganese Dioxide with Gaseous Sulfur}

\subsubsection{Phase Transformation during Reduction Roasting}

Chemically pure $\mathrm{MnO}_{2}$ was used to investigate phase transformation. The phase composition of the roasted samples under different conditions is plotted in Figure 6. $\mathrm{MnO}_{2}$ was absent in all the XRD patterns. Instead, manganese oxides $\left(\mathrm{Mn}_{2} \mathrm{O}_{3}, \mathrm{Mn}_{3} \mathrm{O}_{4}\right.$, or $\left.\mathrm{MnO}\right)$, manganese sulfate $\left(\mathrm{MnSO}_{4}\right)$, and manganese sulfide $(\mathrm{MnS})$ were observed. Nevertheless, the difference between these XRD patterns was distinct. At a fixed roasting temperature of $450{ }^{\circ} \mathrm{C}$ and $\mathrm{S}_{2} / \mathrm{MnO}_{2}$ molar ratio of 0.17 , the phases in the roasted samples contained $\mathrm{Mn}_{2} \mathrm{O}_{3}, \mathrm{Mn}_{3} \mathrm{O}_{4}$, and $\mathrm{MnSO}_{4}$. This implies that $\mathrm{MnO}_{2}$ was reduced stepwise to form lowvalence oxides and $\mathrm{MnSO}_{4}$, which is consistent with the results in Table 2 (Equations (4)-(7)). As the $\mathrm{S}_{2} / \mathrm{MnO}_{2}$ molar ratio increased to 0.25 , the peak intensities of $\mathrm{Mn}_{2} \mathrm{O}_{3}$ and $\mathrm{Mn}_{3} \mathrm{O}_{4}$ decreased, but MnS was observed distinctly. According to the thermodynamic analysis (Equations (8)-(11)), $\mathrm{Mn}_{3} \mathrm{O}_{4}$ was preferentially reduced to $\mathrm{MnO}$ and $\mathrm{MnSO}_{4}$ (Equation (9)). This phenomenon is different from the reaction between $\mathrm{Mn}_{3} \mathrm{O}_{4}$ and solid/liquid sulfur, where MnS was more easily formed [24,25]. The formation of MnS may be attributed to the reaction between $\mathrm{MnO}$ and gaseous sulfur (Equations (12) and (13)), and requires further investigation. With an increase in the $\mathrm{S}_{2} / \mathrm{MnO}_{2}$ molar ratio to 0.50 , the formation of $\mathrm{MnS}$ intensified. However, the peaks of $\mathrm{Mn}_{3} \mathrm{O}_{4}$ were still observed in the XRD patterns. The phase composition of the samples roasted at $400{ }^{\circ} \mathrm{C}$ and $450{ }^{\circ} \mathrm{C}$ was similar. However, a small amount of $\mathrm{MnO}$ was observed in the XRD pattern for roasting at $500{ }^{\circ} \mathrm{C}$. An increase in the roasting temperature contributed to the formation of $\mathrm{MnO}$, which is consistent with the results in Table 2. Compared with the thermodynamic analysis, the difference in the phase composition observed experimentally may also be affected by kinetic factors, which were not investigated in this study. Although the boiling point of sulfur was approximately $470{ }^{\circ} \mathrm{C}$, sulfur can also sublimate below its boiling point. Consequently, the manganese oxides were already reduced at temperatures below $470{ }^{\circ} \mathrm{C}$.

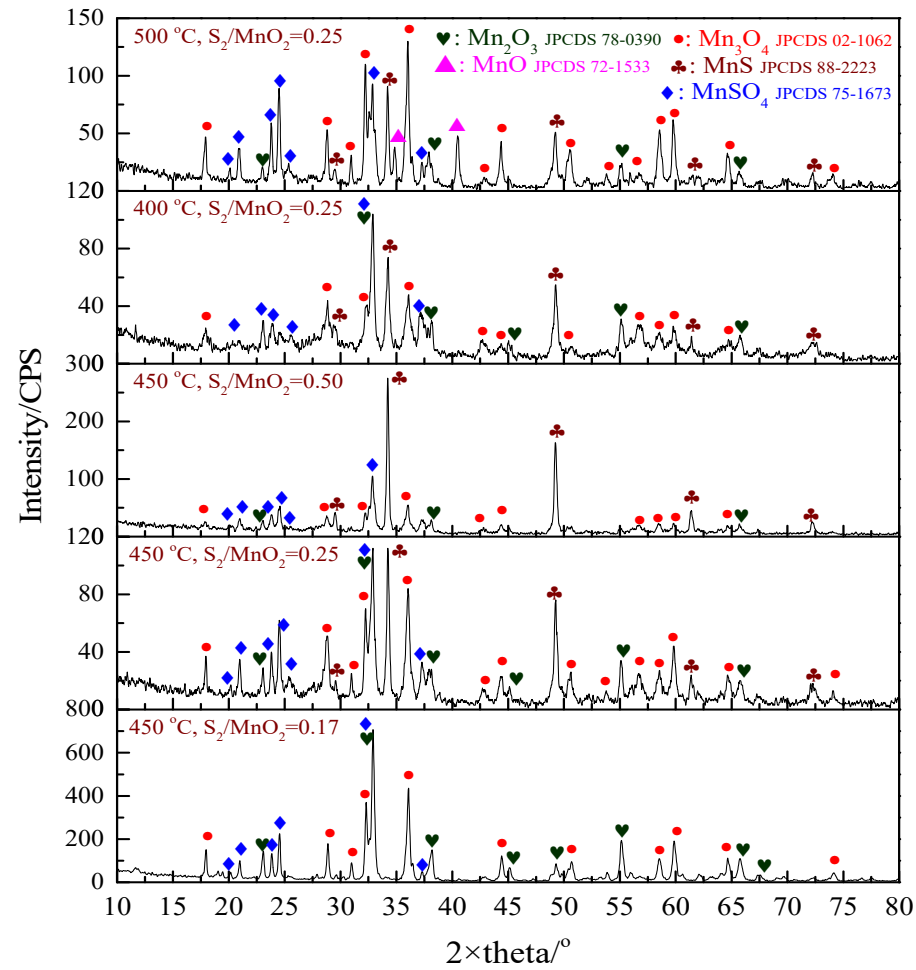

Figure 6. XRD patterns of roasted products as functions of roasting temperature and $\mathrm{S}_{2} / \mathrm{MnO}_{2}$ molar ratio (roasting time: $30 \mathrm{~min}$ ). 


\subsubsection{XPS Analysis}

XPS was conducted to investigate the electronic structure of the main elements on the surface of the roasted samples. XPS fitting parameters for Mn 2p and S 2p were listed in Table 3. Figure 7 shows the XPS profiles (Mn 2p and S 2p) of the samples obtained at various temperatures. The $\mathrm{Mn} 2 \mathrm{p} 3 / 2$ spectra arise from three valence states, $\mathrm{Mn}^{2+}$ (640.4-641.7 eV), $\mathrm{Mn}^{3+}(641.7-641.9 \mathrm{eV})$, and $\mathrm{Mn}^{4+}(641.9-642.6 \mathrm{eV})[27,28]$, which indicates that the manganese oxides were not completely reduced to $\mathrm{Mn}^{2+} . \mathrm{Mn}^{3+}$ and $\mathrm{Mn}^{4+}$ mainly combined with oxygen to form a $\mathrm{Mn}-\mathrm{O}$ bond, whereas $\mathrm{Mn}^{2+}$ may have combined with oxygen $(\mathrm{Mn}-\mathrm{O})$ or sulfur $(\mathrm{Mn}-\mathrm{S})$. The XPS results were in line with the XRD results except for the presence of $\mathrm{Mn}^{4+}$. This difference between the XPS and XRD results may be attributed to the fact that XPS is a surface-sensitive analysis; alternatively, the low content of $\mathrm{Mn}^{4+}$ may not have been detected by XRD. Furthermore, the effect of roasting temperature on the XPS results for Mn was not significant. This is because XPS is a surface analysis technique. The S $2 \mathrm{p}$ profiles of the products contained two types of S species, $\mathrm{SO}_{4}{ }^{2-}$ (168.1-169.6 eV) and $S^{2-}(161.4-163.5 \mathrm{eV})$ [28,29], which indicated the presence of $\mathrm{MnSO}_{4}$ and $\mathrm{MnS}$. However, $\mathrm{S}^{2-}$ was not apparent at temperatures above $500{ }^{\circ} \mathrm{C}$. The results were partly consistent with the XRD patterns and thermodynamic analysis. As discussed before, an increase in the roasting temperature contributed to the formation of $\mathrm{MnO}$.

Table 3. XPS fitting parameters for Mn 2p and S 2p.

\begin{tabular}{cccc}
\hline Temperature $/{ }^{\circ} \mathrm{C}$ & Type & FWHM/ev & Atomic/\% \\
\hline & $\mathrm{Mn}^{2+}$ & 2.00 & 48.65 \\
& $\mathrm{Mn}^{3+}$ & 1.98 & 7.56 \\
& $\mathrm{Mn}^{4+}$ & 1.96 & 19.51 \\
& $\mathrm{SO}^{2-}$ & 1.32 & 18.25 \\
& $\mathrm{~S}^{2-}$ & 1.48 & 6.03 \\
\hline \multirow{2}{*}{400} & $\mathrm{Mn}^{2+}$ & 2.00 & 39.33 \\
& $\mathrm{Mn}^{3+}$ & 1.98 & 9.16 \\
& $\mathrm{Mn}^{4+}$ & 1.75 & 12.59 \\
& $\mathrm{SO}^{2-}$ & 1.18 & 34.22 \\
& $\mathrm{~S}^{2-}$ & 1.39 & 4.70 \\
\hline & $\mathrm{Mn}^{2+}$ & 2.00 & 36.06 \\
& $\mathrm{Mn}^{3+}$ & 1.98 & 7.61 \\
& $\mathrm{Mn}^{4+}$ & 1.82 & 13.89 \\
& $\mathrm{SO}^{2-}$ & 1.16 & 42.44 \\
& $\mathrm{Mn}^{2+}$ & 2.00 & 39.94
\end{tabular}



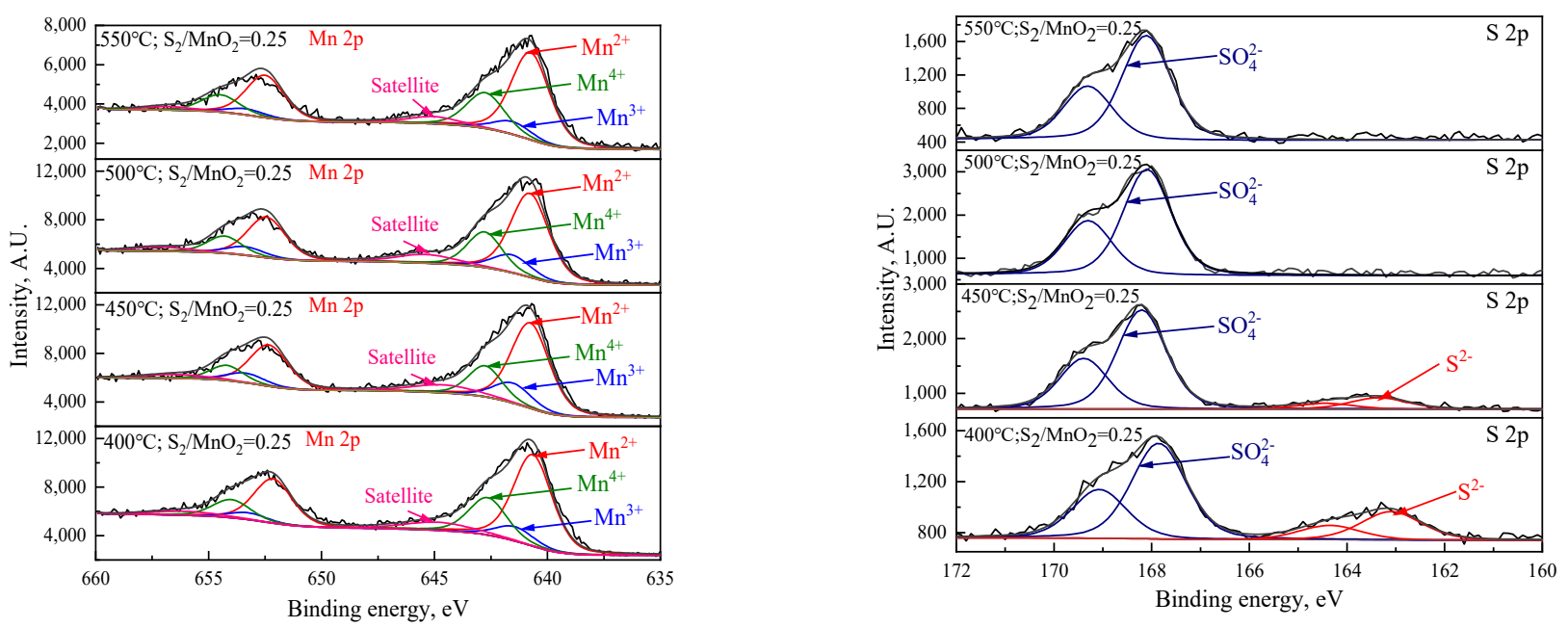

Figure 7. XPS analysis of roasted products as functions of roasting temperature and $\mathrm{S}_{2} / \mathrm{MnO}_{2}$ molar ratio (roasting time: $30 \mathrm{~min}$ ).

\subsubsection{Morphological Analysis of the Reduced Products}

SEM and EDS were used to characterize the microstructure and elemental distribution of the roasted products, respectively. Figure 8 shows the SEM images of the samples roasted under different conditions. Three main phases can be observed, according to the morphology of these samples. The flaky structure belongs to $\mathrm{MnO}$ or $\mathrm{MnS}$, because both have similar crystal textures. The larger columnar granule is $\mathrm{MnSO}_{4}$, and the sporadically distributed particles are low-valence manganese oxides. By increasing the roasting temperature, the crystal sizes increased gradually. As the $\mathrm{S}_{2} / \mathrm{MnO}_{2}$ molar ratio increased, the proportion of the flaky structure increased. This implies that an increase in the amount of sulfur contributed to the formation of MnS. With increasing roasting temperature, the grain size correspondingly increased. Figure 9 shows the EDS profiles of the samples roasted at $450{ }^{\circ} \mathrm{C}$ for 30 min with a $\mathrm{S}_{2} / \mathrm{MnO}_{2}$ molar ratio of 0.25 . It was difficult to distinguish the different phases based on the EDS results, as $\mathrm{Mn}, \mathrm{S}$, and $\mathrm{O}$ were present in all phases. The contents of $\mathrm{Mn}, \mathrm{S}$, and $\mathrm{O}$ varied widely. Spots 1 and 4 exhibited higher $\mathrm{S}$ content, while spots 2 and 3 exhibited lower $O$ content.

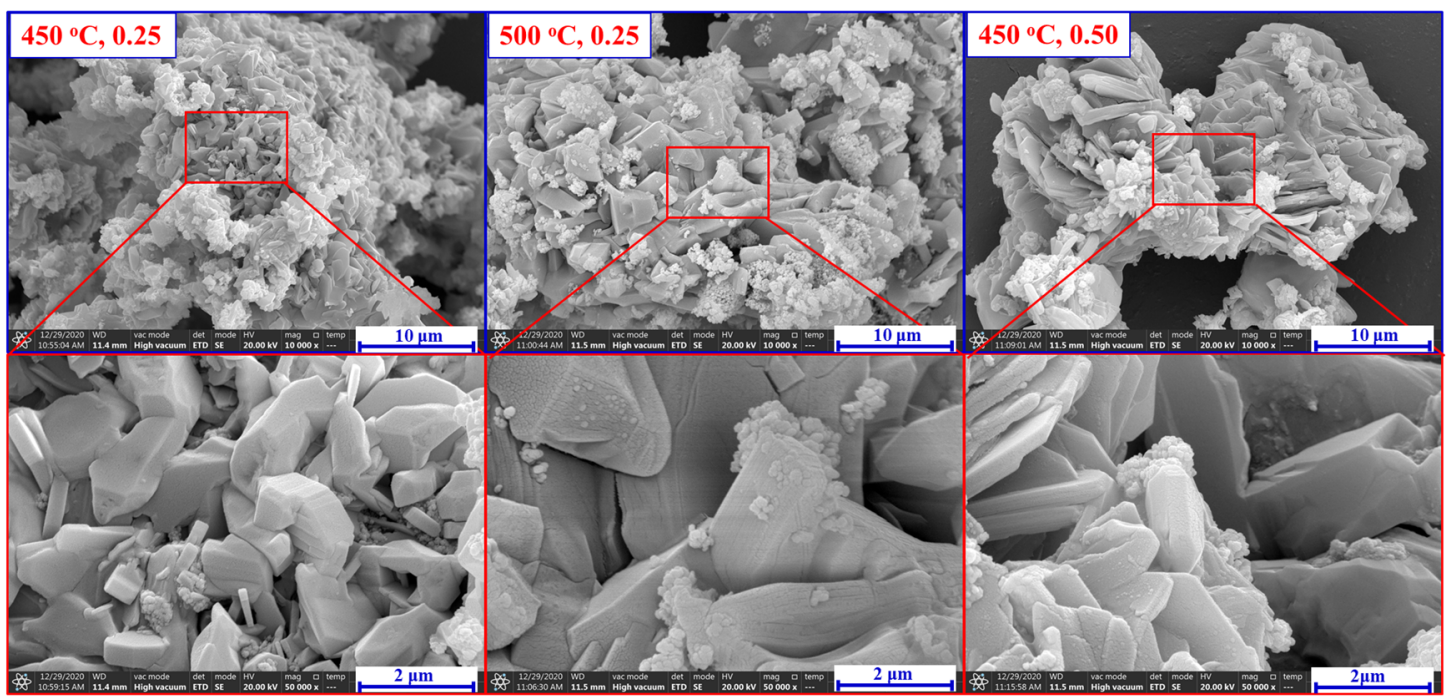

Figure 8. SEM images of samples roasted under different conditions. 


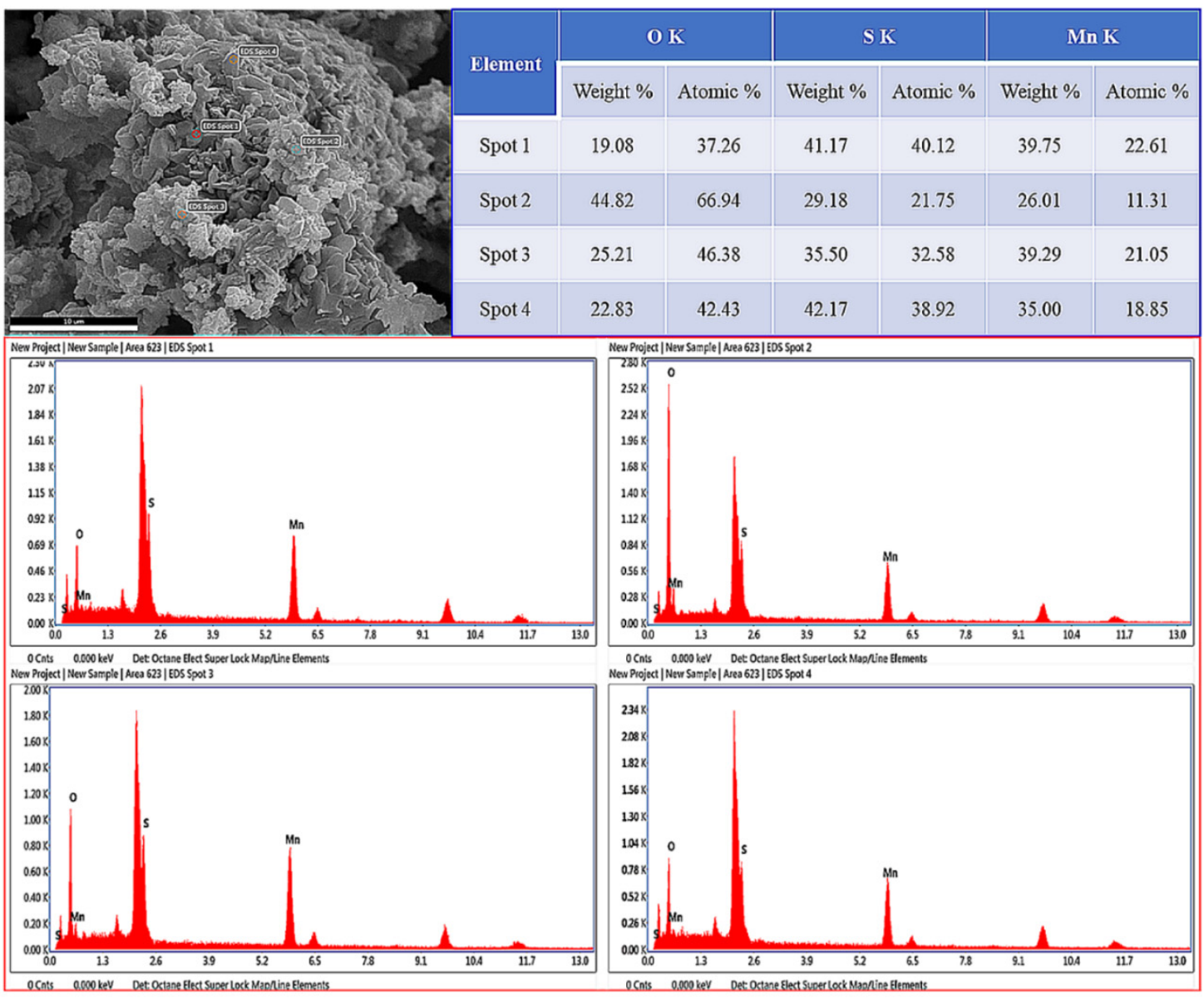

Figure 9. EDS results of the samples roasted at $450{ }^{\circ} \mathrm{C}\left(\mathrm{S}_{2} / \mathrm{MnO}_{2}=0.25,30 \mathrm{~min}\right)$.

\subsubsection{Discussion of Reaction Mechanism}

Based on the thermodynamic calculation and experimental results, the reaction mechanism of $\mathrm{MnO}_{2}$ with gaseous sulfur is illustrated in Figure 10. The reaction is a typical gas-solid chemical reaction, which can be described by an unreacted nuclear model. During reduction, the gaseous reactant diffused continuously to the surface of the particles, the unreacted core gradually shrank and was wrapped by solid products, and the gaseous products reached the main gas stream through the solid product layer. In general, heating did not destroy the structure of the raw material. Upon heating and reduction, solid sulfur $\left(\mathrm{S}_{8}\right)$ sublimated and decomposed to gaseous sulfur with small molecules $\left(\mathrm{S}_{7}, \mathrm{~S}_{6}\right.$ $\left.\ldots \mathrm{S}_{2}, \mathrm{~S}\right) . \mathrm{MnO}_{2}$ was then reduced stepwise to form products in the following order: $\mathrm{Mn}_{2} \mathrm{O}_{3} \rightarrow \mathrm{Mn}_{3} \mathrm{O}_{4} \rightarrow \mathrm{MnO} \rightarrow \mathrm{MnS}$. This reduction was accompanied by the formation of $\mathrm{MnSO}_{4}$. Theoretically, $\mathrm{MnO}$ was more easily formed than $\mathrm{MnS}$ under the current experimental conditions. However, MnS was inevitably generated as the reductant established contact with $\mathrm{MnO}$. Gaseous sulfur must diffuse through the product layers to react with the unreacted nuclei. Thus, MnS was formed, and could not be reduced further. Reduction was inhibited as the product layer thickened, which hindered the diffusion of gaseous sulfur. In addition, $\mathrm{MnSO}_{4}$ reacted with gaseous sulfur to form $\mathrm{MnS} / \mathrm{MnO}$ and $\mathrm{SO}_{2}$ in cases where the reductant was in excess. 


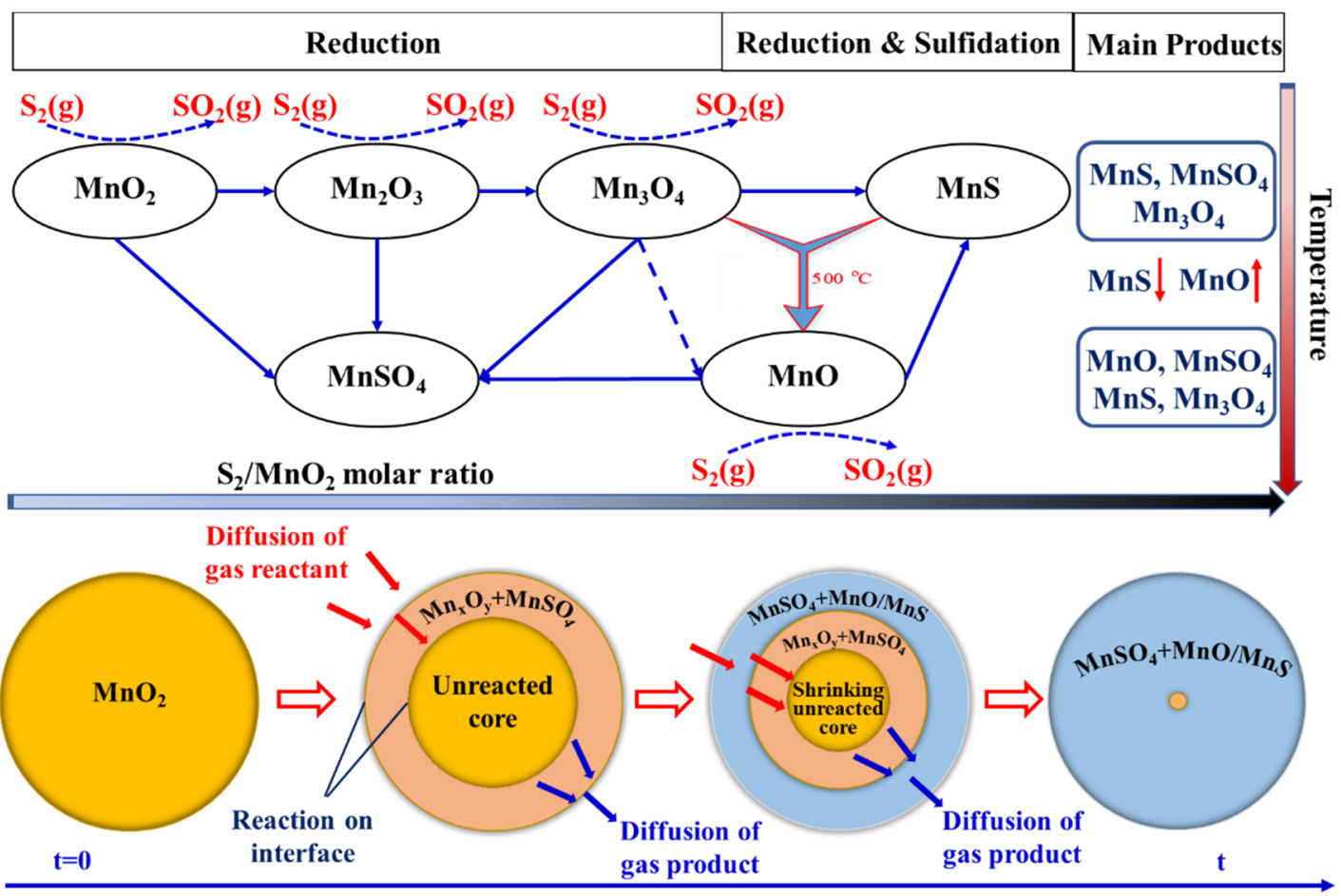

Figure 10. Schematic diagram of the reaction mechanism between manganese dioxide and gaseous sulfur.

\subsection{Extraction of $M n$ from $M n$ Ore}

\subsubsection{Effect of Roasting Temperature}

$\mathrm{MnO}_{2}$ is insoluble in an acidic environment. Therefore, to extract $\mathrm{Mn}$ from manganese oxide ore, $\mathrm{MnO}_{2}$ must be reduced to a bivalent state. $\mathrm{MnO}$ and $\mathrm{MnS}$ are acid-soluble and $\mathrm{MnSO}_{4}$ can be leached by water. Leaching experiments were conducted to evaluate the conversion of $\mathrm{MnO}_{2}$ to low-valence compounds during roasting. Manganese oxide ore was used as the raw material in the leaching experiments. The roasted products were leached by $1 \mathrm{M} \mathrm{H}_{2} \mathrm{SO}_{4}$ as well as deionized water. The leaching conditions were fixed according to the literature [24] as follows: a leaching temperature of $25^{\circ} \mathrm{C}$, leaching time of $10 \mathrm{~min}$, liquid/solid ratio of 5, and rotating speed of $200 \mathrm{rpm}$.

The effect of the roasting temperature on Mn extraction was investigated by maintaining a roasting time of $30 \mathrm{~min}$ and $\mathrm{S}_{2} / \mathrm{MnO}_{2}$ molar ratio of 0.50 . The results in Figure 11 indicate that more than $95.0 \mathrm{wt} \% \mathrm{Mn}$ was leached by acid at temperatures above $400{ }^{\circ} \mathrm{C}$; the leached amount subsequently remained almost constant. When the roasting temperature was increased to $550{ }^{\circ} \mathrm{C}$, the amount of Mn extracted by water leaching increased continuously from 17.5 to $35.9 \mathrm{wt} \%$, indicating that increasing temperature contributed to the formation of $\mathrm{MnSO}_{4}$. According to the thermodynamic analysis in Figure 5, for a fixed $\mathrm{S}_{2} / \mathrm{MnO}_{2}$ molar ratio of 0.50 , the solid products were $\mathrm{MnS}$ and $\mathrm{MnSO}_{4}$, derived from the reaction between $\mathrm{S}_{2}(\mathrm{~g})$ and $\mathrm{MnO}$. Hence, the enhanced $\mathrm{Mn}$ extraction by water leaching may be due to kinetic factors arising with increasing roasting temperature. 


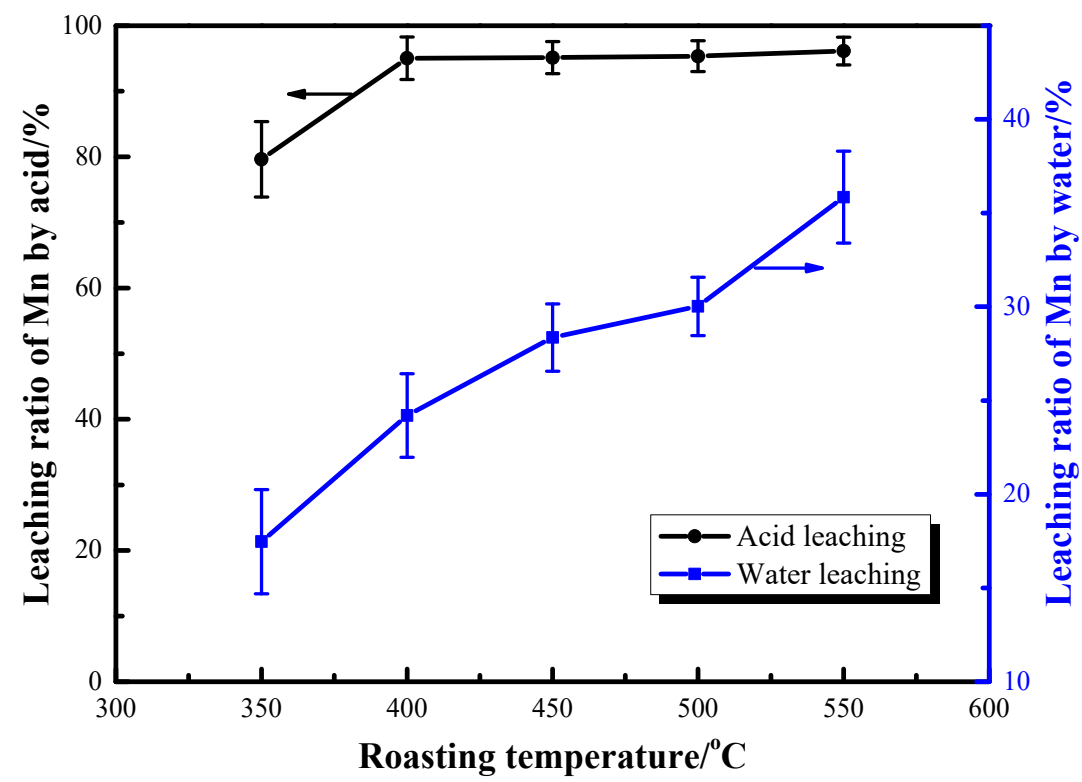

Figure 11. Effect of roasting temperature on the leaching ratio of $\mathrm{Mn}\left(30 \mathrm{~min}, \mathrm{~S}_{2} / \mathrm{MnO}_{2}: 0.5\right)$.

\subsubsection{Effect of Roasting Time}

The amount of Mn extracted as a function of roasting time is plotted in Figure 12. Reduction roasting was carried out at $450{ }^{\circ} \mathrm{C}$ with a $\mathrm{S}_{2} / \mathrm{MnO}_{2}$ molar ratio of 0.5 . The amount of Mn extracted by acid leaching increased from 71.6 to $95.2 \mathrm{wt} \%$ as the roasting time increased from 10 to $30 \mathrm{~min}$, and remained almost unchanged after $30 \mathrm{~min}$. Nevertheless, the amount of Mn extracted by water leaching increased continuously to approximately $28 \mathrm{wt} \%$ with an increase in roasting time, indicating that more $\mathrm{MnSO}_{4}$ was generated. This may be attributed to the fact that $\mathrm{MnO}$ reacted further with $\mathrm{S}_{2}(\mathrm{~g})$ to form $\mathrm{MnS}$ and $\mathrm{MnSO}_{4}$. The results were in good agreement with the thermodynamic analysis. A roasting time of 30 min was sufficient for the acid leaching of $\mathrm{Mn}$.

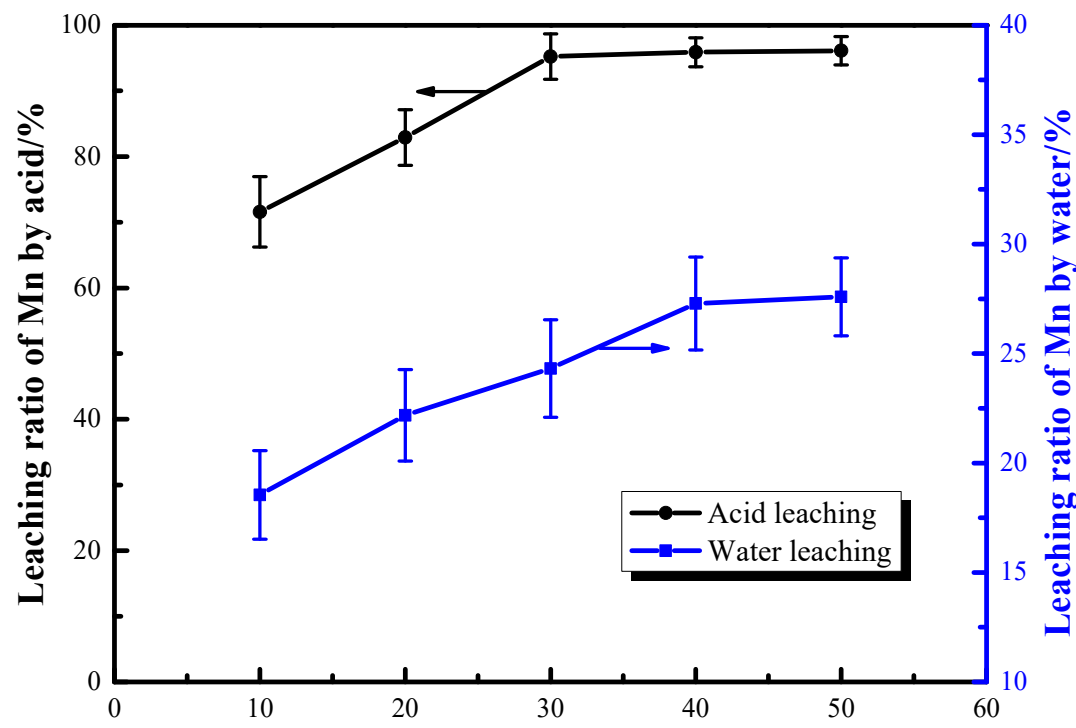

Roasting time/min

Figure 12. Effect of roasting time on the leaching ratio of $\mathrm{Mn}\left(450{ }^{\circ} \mathrm{C}, \mathrm{S}_{2} / \mathrm{MnO}_{2}: 0.5\right)$.

\subsubsection{Effect of $\mathrm{S}_{2} / \mathrm{MnO}_{2}$ Molar Ratio}

The effect of the $\mathrm{S}_{2} / \mathrm{MnO}_{2}$ molar ratio on $\mathrm{Mn}$ extraction was investigated by varying the molar ratio from 0.25 to 0.50 . Several experiments were conducted at $450{ }^{\circ} \mathrm{C}$ for $30 \mathrm{~min}$. 
The results in Figure 13 indicate that as the $\mathrm{S}_{2} / \mathrm{MnO}_{2}$ molar ratio increased from 0.25 to 0.40 , the amount of $\mathrm{Mn}$ leached by acid increased distinctly from 51.6 to $94.5 \mathrm{wt} \%$. Furthermore, the amount of Mn extracted by water leaching increased from 18.5 to $23.3 \mathrm{wt} \%$. According to our previous studies, even if the manganese oxides were not reduced to $\mathrm{Mn}^{2+}$-bearing compounds, the intermediate oxides (such as $\mathrm{Mn}_{3} \mathrm{O}_{4}$ ) would also be dissolved in the acid solution by the following reaction. Thus, a further increase in the amount of sulfur would mildly affect Mn extraction via acid leaching and water leaching.

$$
4 \mathrm{Mn}_{3} \mathrm{O}_{4}+\mathrm{MnS}+12 \mathrm{H}_{2} \mathrm{SO}_{4} \rightarrow 13 \mathrm{MnSO}_{4}+12 \mathrm{H}_{2} \mathrm{O}
$$

The chemical composition of the leached residue obtained by acid leaching is plotted in Table 4. The content of $\mathrm{MnO}_{2}$ was low, at $3.35 \mathrm{wt} \%$, while other components were enriched. Only $3.5 \mathrm{wt} \%$ of Fe was extracted, resulting in the enrichment of Fe in the residue and part of $\mathrm{Fe}_{2} \mathrm{O}_{3}$ has been reduced to $\mathrm{Fe}_{3} \mathrm{O}_{4}$. The leached residue can be used as a raw material in ironmaking.

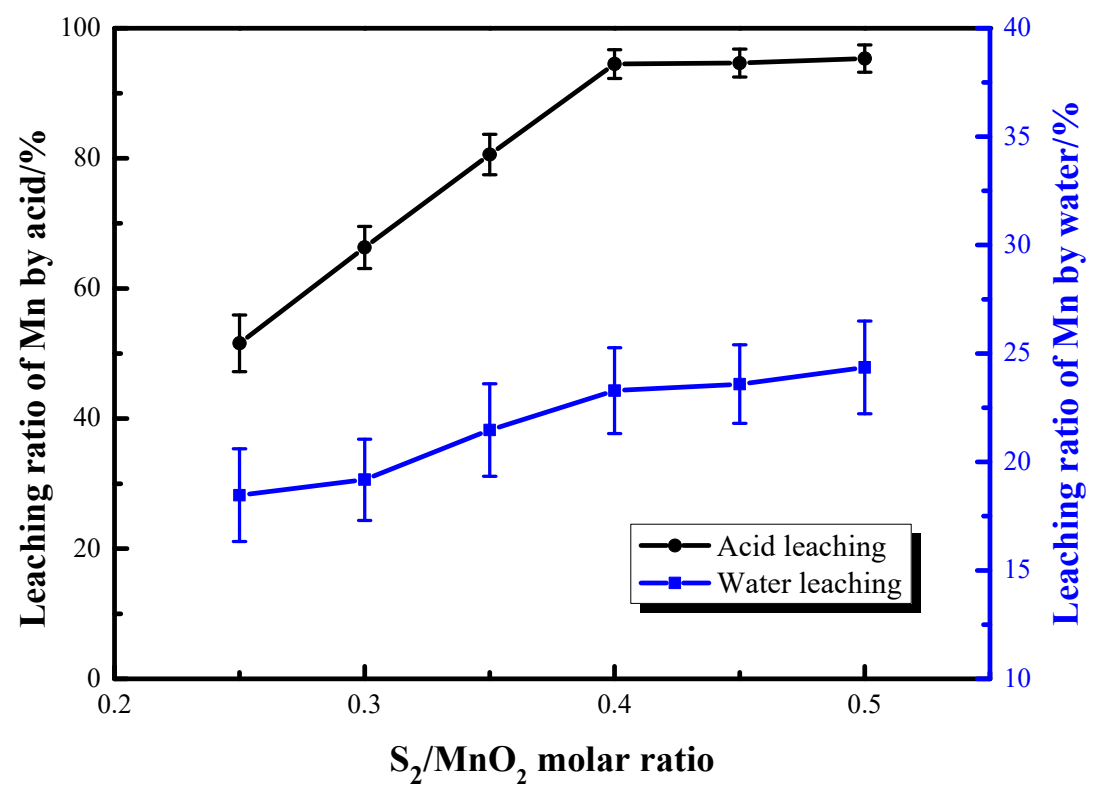

Figure 13. Effect of $\mathrm{S}_{2} / \mathrm{MnO}_{2}$ molar ratio on the leaching ratio of $\mathrm{Mn}\left(450^{\circ} \mathrm{C}, 30 \mathrm{~min}\right)$.

Table 4. Main chemical composition of the leached residue, $\mathrm{wt} \%$.

\begin{tabular}{cccccccc}
\hline Composition & $\mathrm{MnO}_{2}$ & $\mathrm{Fe}_{2} \mathrm{O}_{3}$ & $\mathrm{Fe}_{3} \mathrm{O}_{4}$ & $\mathrm{SiO}_{2}$ & $\mathrm{CaO}$ & $\mathbf{M g O}$ & $\mathrm{Al}_{2} \mathrm{O}_{3}$ \\
\hline Content & 3.35 & 25.26 & 45.47 & 15.02 & 0.65 & 0.57 & 9.78 \\
\hline
\end{tabular}

\section{Conclusions}

In this study, the reaction mechanism between $\mathrm{MnO}_{2}$ and gaseous sulfur was investigated in detail. The following conclusions can be drawn:

(1). Thermodynamically, the reduction of $\mathrm{MnO}_{2}$ by gaseous sulfur was feasible and easy. Solid sulfur sublimated and decomposed to form small molecules of sulfur gases. The phase composition depended on the temperature and input mole fraction of sulfur.

(2). $\mathrm{MnO}_{2}$ was reduced stepwise to low-valence manganese oxides, and manganese sulfate was generated simultaneously. The reaction process could be described by an unreacted nuclear model. The phase composition of the roasted products was complicated and MnS was inevitably formed, although the formation of $\mathrm{MnO}$ was thermodynamically easier than that of $\mathrm{MnS}$.

(3). Mn was extracted by $\mathrm{H}_{2} \mathrm{SO}_{4}$ solution from manganese oxide ore after reduction by gaseous sulfur. A Mn extraction of $95.2 \mathrm{wt} \%$ was achieved in $\mathrm{H}_{2} \mathrm{SO}_{4}$ solution with a 
roasting temperature of $450{ }^{\circ} \mathrm{C}$, roasting time of $30 \mathrm{~min}$, and $\mathrm{S}_{2} / \mathrm{MnO}_{2}$ molar ratio of 0.40 . The Mn extraction in deionized water was $24.3 \mathrm{wt} \%$, while Fe was extracted in traces.

Author Contributions: Data collection, Y.L. and F.H.; data analysis, Y.L. and F.H.; literature search, D.M. and Q.H.; figures, D.M. and Q.H.; study design and experimental operations, Y.L. and Z.Y.; writing —original draft preparation, Y.L. and Z.Y.; writing—review and editing Z.Y. All authors have read and agreed to the published version of the manuscript.

Funding: The authors are grateful to the National Natural Science Foundation of China (Grant No. 51904047), the Fundamental and Frontier Research Project of Chongqing, China (cstc2020jcyjmsxmX0515), and the Fundamental Research Funds for the Central Universities (2020CDJ-LHZZ-083) for the financial support of this research.

Data Availability Statement: Not applicable.

Conflicts of Interest: The authors declare no conflict of interest.

\section{References}

1. Liu, B.B.; Zhang, Y.B.; Lu, M.M.; Su, Z.J.; Li, G.H.; Jiang, T. Extraction and separation of manganese and iron from ferruginous manganese ores: A review. Miner. Eng. 2019, 131, 286-303. [CrossRef]

2. Liu, B.B.; Zhang, Y.B.; Wang, J.; Su, Z.J.; Li, G.H.; Jiang, T. A further investigation on the $\mathrm{MnO}_{2}-\mathrm{Fe}_{2} \mathrm{O}_{3}$ system roasted under CO- $\mathrm{CO}_{2}$ atmosphere. Adv. Powder Technol. 2019, 30, 302-310. [CrossRef]

3. Yuan, S.; Zhou, W.T.; Han, Y.X.; Li, Y.J. Separation of manganese and iron for low-grade ferromanganese ore via fluidization magnetization roasting and magnetic separation technology. Miner. Eng. 2020, 152, 106359. [CrossRef]

4. Zhang, X.R.; Liu, Z.H.; Wu, X.B.; Du, J.; Tao, C.Y. Electric field enhancement in leaching of manganese from low-grade manganese dioxide ore: Kinetics and mechanism study. J. Electroanal. Chem. 2017, 788, 165-174. [CrossRef]

5. Coetsee, T. The role of manganese ore reduction morphology development in setting reduction mechanisms. Miner. Eng. 2019, 137, 217-231. [CrossRef]

6. Deng, L.; Qu, B.; Su, S.J.; Ding, S.L.; Sun, W.Y. Extraction of iron and manganese from pyrolusite absorption residue by ammonium sulphate roasting-leaching Process. Metals 2018, 8, 38. [CrossRef]

7. Cai, X.N.; Shen, F.; Zhang, Y.J.; Hu, H.Y.; Huang, Z.Q.; Yin, Y.Z.; Liang, X.T.; Qin, Y.B.; Liang, J. Mineralization of organics in hazardous waste sulfuric acid by natural manganese oxide ore and a combined $\mathrm{MnO}_{2}$ /activated carbon treatment to produce qualified manganese sulfate. J. Hazard. Mater. 2019, 366, 466-474. [CrossRef]

8. Cai, Z.L.; Feng, Y.L.; Li, H.R.; Liu, X.W. Response Surface Optimization of Reductive Leaching Manganese from Low-Grade Pyrolusite Using Biogas Residual as Reductant. Miner. Process. Extr. Metall. Rev. 2015, 36, 1-6. [CrossRef]

9. Tu, Z.B.; Liang, X.P.; Wang, Y.; Wu, C.B. Removal of Phosphorus from High-Phosphorus Manganese Ores by AmmoniaAmmonium Carbonate Leaching Method. Metals 2019, 9, 1354. [CrossRef]

10. Gao, L.H.; Liu, Z.G.; Pan, Y.Z.; Feng, C.; Ge, Y.; Chu, M.S. A study on separation of Mn and Fe from high-alumina ferruginous manganese ores by the carbothermal roasting reduction process. Adv. Powder Technol. 2020, 31, 51-60. [CrossRef]

11. Abou-El-Sherbini, K.S. Simultaneous extraction of manganese from low grade manganese dioxide ore and beneficiation of sulfur slag. Sep. Purif. Technol. 2002, 27, 67-75. [CrossRef]

12. Sun, W.Y.; Su, S.J.; Wang, Q.Y.; Ding, S.L. Lab-scale circulation process of electrolytic manganese production with low-grade pyrolusite leaching by $\mathrm{SO}_{2}$. Hydrometallurgy 2013, 133, 118-125. [CrossRef]

13. Das, P.K.; Anand, S.; Das, R.P. Studies on reduction of manganese dioxide by $\left(\mathrm{NH}_{4}\right)_{2} \mathrm{SO}_{3}$ in ammonical medium. Hydrometallurgy 1998, 50, 39-49. [CrossRef]

14. Bafghi, M.S.; Zakeri, A.; Ghasemi, Z.; Adeli, M. Reductive dissolution of manganese ore in sulfuric acid in the presence of iron metal. Hydrometallurgy 2008, 90, 207-212. [CrossRef]

15. Lin, S.D.; Gao, L.; Yang, Y.; Chen, J.; Guo, S.H.; Omran, M.; Chen, G. Dielectric properties and high temperature thermochemical properties of the pyrolusite-pyrite mixture during reduction roasting. J. Mater. Res. Technol. 2020, 9, 13128-13136. [CrossRef]

16. Sinha, M.K.; Purcell, W.; Van der Westhuizen, W.A. Recovery of manganese from ferruginous manganese ore using ascorbic acid as reducing agent. Miner. Eng. 2020, 154, 106406. [CrossRef]

17. Xiong, S.F.; Li, X.; Liu, P.L.; Hao, S.H.; Hao, F.; Yin, Z.L.; Liu, J.X. Recovery of manganese from low-grade pyrolusite ore by reductively acid leaching process using lignin as a low cost reductant. Miner. Eng. 2018, 125, 126-132. [CrossRef]

18. Jiang, T.; Yang, Y.B.; Huang, Z.C.; Zhang, B.; Qiu, G.Z. Leaching kinetics of pyrolusite from manganese-silver ores in the presence of hydrogen peroxide. Hydrometallurgy 2004, 72, 129-138. [CrossRef]

19. Masotta, M.; Rocchi, I.; Pazzagli, G.; D’Ambrosio, R.; Seggiani, M. Recovery of sulfur from sulfur-rich filter cakes in a rotary kiln: Process. Waste Manage. 2021, 126, 567-577. [CrossRef]

20. Sarapajevaite, G.; Baltakys, K. Purification of sulfur waste under hydrothermal conditions. Waste Biomass Valorization 2021, 12, 3407-3416. [CrossRef] 
21. Yang, K.; Zhang, L.B.; Zhu, X.C.; Peng, J.H.; Li, S.W.; Ma, A.Y.; Li, H.Y.; Zhu, F. Role of manganese dioxide in the recovery of oxide-sulphide zinc ore. J. Hazard. Mater. 2018, 343, 315-323. [CrossRef] [PubMed]

22. Singh, V.; Srivastava, V.C. Hazardous maize processing industrial sludge: Thermo-kinetic assessment and sulfur recovery by evaporation-condensation technique. J. Hazard. Mater. 2022, 424, 127477. [CrossRef] [PubMed]

23. Wagenfeld, J.G.; Al-Ali, K.; Almheiri, S.; Slavens, A.F.; Calvet, N. Sustainable applications utilizing sulfur, a by-product from oil and gas industry: A state-of-the-art review. Waste Manage. 2019, 95, 78-89. [CrossRef]

24. Zhang, Y.B.; You, Z.X.; Li, G.H.; Jiang, T. Manganese extraction by sulfur-based reduction roasting-acid leaching from low-grade manganese oxide ores. Hydrometallurgy 2013, 133, 126-132. [CrossRef]

25. You, Z.X.; Li, G.H.; Dang, J.; Yu, W.Z.; Lv, X.W. The mechanism on reducing manganese oxide ore with elemental sulfur. Powder Technol. 2018, 330, 310-316. [CrossRef]

26. Liu, J.G. An Ebullated Furnace for Manganese Oxide Reduction with Automatic Feeding Device. Patent CN201220155781.8, 13 April 2012. (In Chinese).

27. Nesbitt, H.W.; Banerjee, D. Interpretation of XPS Mn(2p) spectra of Mn oxyhydroxides and constraints on the mechanism of $\mathrm{MnO}_{2}$ precipitation. Am. Mineral. 1998, 83, 305-315. [CrossRef]

28. Xin, Y.; Cao, L.Y.; Huang, J.F.; Liu, J.; Fei, J.; Yao, C.Y. Influence of S/Mn molar ratio on the morphology and optical property of $\gamma-\mathrm{MnS}$ thin films prepared by microwave hydrothermal. J. Alloys Compd. 2013, 549, 1-5.

29. Taleatu, B.A.; Arbab, E.A.A.; Mola, G.T. Stable $\alpha-M n S$ thin film deposited by two-electrode cell: Synthesis, structural characterization and photoemission spectroscopic studies. Appl. Phys. A 2015, 120, 959-965. [CrossRef] 